\title{
GnRH Neurons of Young and Aged Female Rhesus Monkeys Co-Express GPER but Are Unaffected by Long-Term Hormone Replacement
}

\author{
Michelle M. Naugle ${ }^{a}$ Andrea C. Gore ${ }^{a-c}$ \\ a Institute for Neuroscience, ${ }^{b}$ Pharmacology and Toxicology, College of Pharmacy, and \\ 'Institute for Cellular and Molecular Biology, University of Texas at Austin, Austin, Tex., USA
}

\section{Key Words}

G protein-coupled estrogen receptor - Gonadotropinreleasing hormone $\cdot$ Aging $\cdot$ Monkey $\cdot$ Hypothalamus . Estrogen · Progesterone $\cdot$ Menopause $\cdot$ Median eminence

\begin{abstract}
Menopause is caused by changes in the function of the hypothalamic-pituitary-gonadal axis that controls reproduction. Hypophysiotropic gonadotropin-releasing hormone $(\mathrm{GnRH})$ neurons in the hypothalamus orchestrate the activity of this axis and are regulated by hormonal feedback loops. The mechanisms by which $\mathrm{GnRH}$ responds to the primary regulatory sex steroid hormone, estradiol $\left(E_{2}\right)$, are still poorly understood in the context of menopause. Our goal was to determine whether the $G$ protein-coupled estrogen receptor (GPER) is co-expressed in adult primate GnRH neurons and whether this changes with aging and/or $E_{2}$ treatment. We used immunofluorescence double-labeling to characterize the co-expression of GPER in GnRH perikarya and terminals in the hypothalamus. Young and aged rhesus macaques were ovariectomized and given long-term ( $\sim 2-$ year) hormone treatments $\left(E_{2}, E_{2}+\right.$ progesterone, or vehicle)
\end{abstract}

selected to mimic currently prescribed hormone replacement therapies used for the alleviation of menopausal symptoms in women. We found that about half of $\mathrm{GnRH}$ perikarya co-expressed GPER, while only about $12 \%$ of GnRH processes and terminals in the median eminence (ME) were doublelabeled. Additionally, many GPER-labeled processes were in direct contact with GnRH neurons, often wrapped around the perikarya and processes and in close proximity in the ME. These results extend prior work by showing robust co-localization of GPER in GnRH in a clinically relevant model, and they support the possibility that GPER-mediated $\mathrm{E}_{2}$ regulation of $\mathrm{GnRH}$ occurs both in the soma and terminals in nonhuman primates.

(c) 2014 S. Karger AG, Basel

\section{Introduction}

Menopause is often accompanied by one or more neurobiological symptoms such as hot flushes, depression, irritability, sleep disruptions, lowered energy levels, memory deficiency, sexual dysfunction, and cognitive decline [1-4]. The most common treatment for menopaus-

\section{KARGER}

(c) 2014 S. Karger AG, Basel

0028-3835/14/1004-0334\$39.50/0

E-Mail karger@karger.com

www.karger.com/nen
Andrea C. Gore, $\mathrm{PhD}$

University of Texas at Austin

107 West Dean Keeton, C0875

Austin, TX 78712 (USA)

E-Mail andrea.gore@ austin.utexas.edu 
al symptoms is hormone replacement therapy, used primarily to improve quality of life from vasomotor symptoms, vaginal dryness, and osteoporosis $[5,6]$. However, the termination and subsequent revisitation of results of the Women's Health Initiative has resulted in considerable controversy about the relative benefits and risks of exogenous hormone therapies [7-11]. From the neurobiological perspective, further insights are needed into the complex mechanisms underlying reproductive aging and the effects of hormone replacement therapy on the brain, including the nature of cells that respond to hormones and whether/how this response changes with aging.

In the mediobasal hypothalamus $(\mathrm{MBH})$ of primates, gonadotropin-releasing hormone $(\mathrm{GnRH})$ neurons synthesize a neuropeptide that is released from nerve terminals at capillaries within the median eminence (ME) [1216]. GnRH secretion triggers the release of the gonadotropins from the anterior pituitary that in turn stimulates the production of sex steroid hormones, predominantly estradiol $\left(\mathrm{E}_{2}\right)$ and progesterone $\left(\mathrm{P}_{4}\right)$, in the ovaries. These hormones then feed back onto the hypothalamus and pituitary, ultimately modulating the production and release of GnRH. The anatomical site(s) of $E_{2}$ feedback regulation onto $\mathrm{GnRH}$ neurons involves a combination of both direct and indirect inputs. Previously, $\mathrm{E}_{2}$ regulation of $\mathrm{GnRH}$ cells was thought to be entirely indirectly mediated by other neuronal cell types and/or glia, because $\mathrm{GnRH}$ cells do not co-express estrogen receptor (ER)- $\alpha$ [17]. GnRH cells are now known to contain ER- $\beta$, STXsensitive ERs, and G protein-coupled estrogen receptor (GPER, sometimes called GPR30) [18-23]. Of these, membrane ERs enable GnRH cells to respond rapidly to $\mathrm{E}_{2}$ with increased action potential rates, intracellular $\mathrm{Ca}^{2+}$ oscillations, and GnRH peptide release [23-27].

This study focused on the co-expression of GPER in GnRH neurons, which has not been well characterized in primates, in the context of reproductive aging. To our knowledge, there has been only a single report showing co-localization of GPER on three GnRH neurons in the primate brain [23]; all other work in this arena was conducted ex vivo or electrophysiologically, and predominantly in the rodent model. Our laboratory recently reported age-related increases in the density of GPER-immunoreactive cells in the arcuate and periventricular nuclei of female rhesus monkeys and confirmed that GPER+ cells are found in regions where GnRH neurons are expressed in the monkey [28]. Considering that GPER can mediate actions of $\mathrm{E}_{2}$ on $\mathrm{GnRH}$ cells, together with known aging-related changes in $\mathrm{GnRH}$ function in the macaque [29], we sought to address three questions: (1) do GnRH neurons of adult monkeys co-express GPER, (2) in what cellular compartment (cell body, nerve terminal) is co-expression found, and (3) how does this coexpression change with age or $\mathrm{E}_{2}$ treatment? Research was conducted in monkeys that were age appropriate for the pre- and perimenopausal stages and that received hormone treatments that more closely approximate current usage since the termination of the Women's Health Initiative.

\section{Methods}

\section{Animals}

A total of 39 rhesus monkeys (Macaca mulatta) of two age ranges were included in this study: young adult $(\mathrm{n}=17$; aged $9.9 \pm$ 2.3 years) and aged $(n=22$; aged $22.6 \pm 1.6$ years). Young animals were all premenopausal, and aged animals were all perimenopausal, as determined by normal cycling lengths of 24-34 days or irregular cycles longer than 35 days, respectively [30]. Cycle length was established by daily visual inspection of vaginal bleeding for 2 years before initiation of the study. Additionally, all of the animals in the aged group were over 19 years because prominent endocrine and neurobiological signs of aging do not occur in monkeys before reaching that age [31]. The animals were housed, and experiments were carried out, at the California National Primate Research Center, as described previously [32-37]. The procedures were approved by the Institutional Animal Care and Use Committee at the University of California and in compliance with the National Institutes of Health Guide for the Care and Use of Laboratory Animals. All of the monkeys were selected based on the following criteria: they had no long-term or invasive dietary or pharmacological interventions, and they were all in good physical health with no physical abnormalities or severe arthritis.

\section{Ovariectomy and Hormone Treatment}

All animals were ovariectomized (OVX), as previously described [32-37]. Briefly, they were sedated with ketamine (10 mg/ $\mathrm{kg})$ and atropine $(0.4 \mathrm{mg} / \mathrm{kg})$ and anesthetized with isoflurane, and their ovaries and fallopian tubes were removed. They were given a 2 - to 3-month recovery period before assignment to one of the three treatment groups designed to mimic current hormone regimens commonly prescribed to women. These consisted of the following conditions: vehicle [young (YV), $\mathrm{n}=7$; aged $(\mathrm{AV}), \mathrm{n}=8$ ], continuous $\mathrm{E}_{2}$ [young $(\mathrm{YE}), \mathrm{n}=5$; aged $(\mathrm{AE}), \mathrm{n}=6$ ], and continuous $\mathrm{E}_{2}+$ cyclic $\mathrm{P}_{4}$ [young (YEP), $\mathrm{n}=5$; aged (AEP), $\mathrm{n}=8$ ].

The duration of all hormone or vehicle treatments was 2 years. Some animals were excluded from the study due to illness or incomplete OVX, as determined by hormone analysis; the numbers reported here are the final numbers used in this study. For the $\mathrm{E}_{2}$ hormone groups, 2 Silastic capsules $(3 \mathrm{~cm}$ long and $0.46 \mathrm{~cm}$ inner diameter) containing crystalline $\mathrm{E}_{2}$ (Sigma-Aldrich, St. Louis, Mo., USA) were implanted subcutaneously between the shoulder blades, achieving a mean serum level of $150 \mathrm{pg} / \mathrm{ml}$, and were replaced every 3 months. The vehicle groups received empty capsules on the same schedule, plus an intramuscular injection of 
$1 \mathrm{ml}$ peanut oil to mimic a fourth treatment group (cyclic $\left.\mathrm{E}_{2}\right)$ that we were unable to include in this study due to the lack of agematched animals. The $\mathrm{E}_{2}+$ cyclic $\mathrm{P}_{4}$ group received $100 \mathrm{mg}$ of micronized $\mathrm{P}_{4}$ (Catalent Pharma Solutions, Somerset, N.J., USA), mimicking luteal phase $\mathrm{P}_{4}$ levels, in their daily fruit treat for 10 out of every 28 days, while the other groups received untreated fruit.

\section{Euthanasia and Tissue Processing}

The monkeys were perfused 8-10 days after the last $\mathrm{P}_{4}$ treatment and on a comparable day for the other (non- $\mathrm{P}_{4}$ ) groups, as previously described $[38,39]$. Briefly, they were deeply anesthetized with ketamine $(25 \mathrm{mg} / \mathrm{kg})$ and pentobarbital $(20-35 \mathrm{mg} / \mathrm{kg})$ and perfused transcardially with ice-cold $1 \%$ paraformaldehyde followed by $4 \%$ paraformaldehyde in phosphate buffer (PB) for 1 and $12 \mathrm{~min}$ (at $185 \mathrm{ml} / \mathrm{min}$ ), respectively. The brain was removed, and the hypothalamus was dissected and then postfixed for $6 \mathrm{~h}$ in $4 \%$ paraformaldehyde and $0.125 \%$ glutaraldehyde in PB and shipped to the University of Texas at Austin in PB for further processing. The $\mathrm{MBH}$ was sectioned at $100 \mu \mathrm{m}$ using a vibrating microtome (Leica VT1000 S; Leica, Bannockburn, Ill., USA). Half of the ME, when present, was dissected for use in companion studies, and the remaining sections were cryoprotected in a sucrose series $(12,18$, and $30 \%$ for $48 \mathrm{~h}$ each $)$ and stored at $-20^{\circ} \mathrm{C}$ in $30 \%$ glycerol for later use.

\section{Immunohistochemistry}

We used double-label fluorescence immunohistochemistry (IHC) to visualize GnRH and GPER distribution in the MBH. Four to 5 sections containing the $\mathrm{MBH}$ were collected from each animal and allocated into rostral, medial, and caudal groups for IHC. There were an uneven number of sections available from each region due to tissue damage and loss from poor perfusions and processing errors. A second IHC run was performed to fill in gaps from animals in the first run in which fewer than $5 \mathrm{GnRH}$ neurons were found. Between each step of the IHC, sections were washed in phosphate-buffered saline (PBS; $\mathrm{pH} 7.4$ ) for $3 \times 10 \mathrm{~min}$. Due to the thickness of the sections, we used a citrate buffer ( $\mathrm{pH} 8.5$; preheated to $70^{\circ} \mathrm{C} ; 30 \mathrm{~min}$ ) for antigen retrieval. Nonspecific binding sites were blocked with a solution of $10 \%$ normal goat serum (NGS; S-1000; Vector Laboratories, Burlingame, Calif., USA) and 2\% bovine serum albumin (Sigma-Aldrich) for $90 \mathrm{~min}$.

We incubated sections for $48 \mathrm{~h}$ (at $4^{\circ} \mathrm{C}$ with constant agitation) in mouse anti-GnRH (HU11b, diluted to 1:1,000; a gift from Dr. Henryk Urbanski) and rabbit anti-GPER primary antibody (diluted 1:1,000; a gift from Dr. Edward Filardo) in 2\% NGS in PBS. We then incubated the sections simultaneously in the following secondary antibodies for $2 \mathrm{~h}$ : Alexa Fluor 594-conjugated goat anti-mouse IgG and Alexa 488 anti-rabbit IgG (both diluted 1:400; Life Technologies, Eugene, Oreg., USA) in a solution of 5\% NGS in PBS. The primary antibodies have been thoroughly validated in rodent and primate tissue [22, 23, 40-45]. Here, the primary antibodies were omitted in the experimental controls, and no specific labeling for either fluorophore was found. To reduce lipofuscin autofluorescence, we treated the tissue with $10 \mathrm{mM} \mathrm{CuSO}_{4}$ in 50 $\mathrm{mM}$ ammonium acetate for $20 \mathrm{~min}$. The sections were then mounted on glass slides, allowed to dry for $10 \mathrm{~min}$, and coverslipped using Vectashield mounting medium (Vector Laboratories). The edges of the coverslip were sealed with clear nail polish. The slides were stored light-protected at $4^{\circ} \mathrm{C}$.
Table 1. Numbers of GnRH perikarya, GnRH+/GPER+ perikarya, and sections per group and region

\begin{tabular}{|c|c|c|c|c|c|c|}
\hline & \multicolumn{3}{|c|}{ Total number } & \multicolumn{3}{|c|}{ Average number } \\
\hline & rostral & medial & caudal & rostral & medial & caudal \\
\hline \multicolumn{7}{|c|}{ GnRH perikarya } \\
\hline YV & 33 & 33 & 11 & 2.1 & 3.5 & 0.8 \\
\hline YE & 37 & 22 & 9 & 2.3 & 3.0 & 1.6 \\
\hline YEP & 36 & 32 & 7 & 2.1 & 3.0 & 1.5 \\
\hline AV & 8 & 46 & 29 & 1.2 & 2.1 & 1.2 \\
\hline $\mathrm{AE}$ & 25 & 34 & 15 & 6.4 & 3.1 & 1.4 \\
\hline AEP & 22 & 26 & 27 & 1.8 & 1.8 & 1.9 \\
\hline \multicolumn{7}{|c|}{ GnRH+/GPER+ perikarya } \\
\hline YV & 7 & 12 & 8 & 0.8 & 2.4 & 1.8 \\
\hline YE & 12 & 8 & 8 & 0.9 & 1.2 & 1.5 \\
\hline YEP & 8 & 5 & 5 & 1.5 & 0.8 & 2.5 \\
\hline $\mathrm{AV}$ & 3 & 14 & 12 & 1.0 & 1.2 & 2.0 \\
\hline $\mathrm{AE}$ & 14 & 19 & 11 & 2.7 & 2.0 & 1.5 \\
\hline AEP & 15 & 12 & 7 & 2.2 & 1.5 & 1.1 \\
\hline \multicolumn{7}{|c|}{ Sections } \\
\hline YV & 16 & 10 & 11 & 2.3 & 1.4 & 1.6 \\
\hline YE & 13 & 6 & 6 & 2.4 & 1.2 & 1.4 \\
\hline YEP & 21 & 10 & 7 & 4.2 & 2.0 & 1.4 \\
\hline $\mathrm{AV}$ & 6 & 20 & 25 & 0.8 & 2.5 & 3.3 \\
\hline $\mathrm{AE}$ & 5 & 12 & 11 & 0.8 & 2.3 & 1.8 \\
\hline AEP & 13 & 13 & 12 & 1.8 & 1.8 & 1.8 \\
\hline
\end{tabular}

\section{Confocal Microscopy}

We used a Zeiss LSM 710 microscope running ZEN Black software (Carl Zeiss International; version date: 2012) with a PlanApochromat $\times 40 / 1.4$ Oil DIC M27 objective for imaging the $\mathrm{MBH}$ of each animal. At the beginning of each imaging session, the laser power, gain, and offset were adjusted using the negative control as a reference. For imaging the perikarya and ME, the two fluorophores were scanned sequentially to prevent signal bleed-through, and the average of two scans for each line was recorded to decrease background. The GnRH scan was done at an excitation wavelength of $561 \mathrm{~nm}$ (detection range 566-689 nm) followed by GPER at an excitation wavelength of $458 \mathrm{~nm}$ (detection range 492-598 nm). To map the distribution of GnRH-immunoreactive (GnRH-IR) cell bodies, we imaged the entire $\mathrm{MBH}$ plus some surrounding regions where hypophysiotropic $\mathrm{GnRH}$ perikarya are distributed $[46,47]$. GnRH neurons are 5-10 $\mu \mathrm{m}$ thick, and to ensure that no $\mathrm{GnRH}$ perikarya would be missed, we took a $\mathrm{z}$-stack with a voxel depth of $5 \mu \mathrm{m}$ and a step size of $9 \mu \mathrm{m}$ through the whole section. GnRH neurons were detected through the entire thickness of the sections, indicating that there was complete penetration of the antibodies. The location of each GnRH-IR neuron was marked as single (GnRH only) or double (GnRH+/GPER+) labeled, on a diagram of the $\mathrm{MBH}$ representing the rostral, medial, and caudal levels based on 4-6 overlapping slices (depending on the neuron orientation; with voxel depths of $2 \mu \mathrm{m}$ ) through each neuron for GnRH-IR followed by GPER-IR. To determine the relationship between GPER-IR and GnRH neuroterminals in the ME, we took 

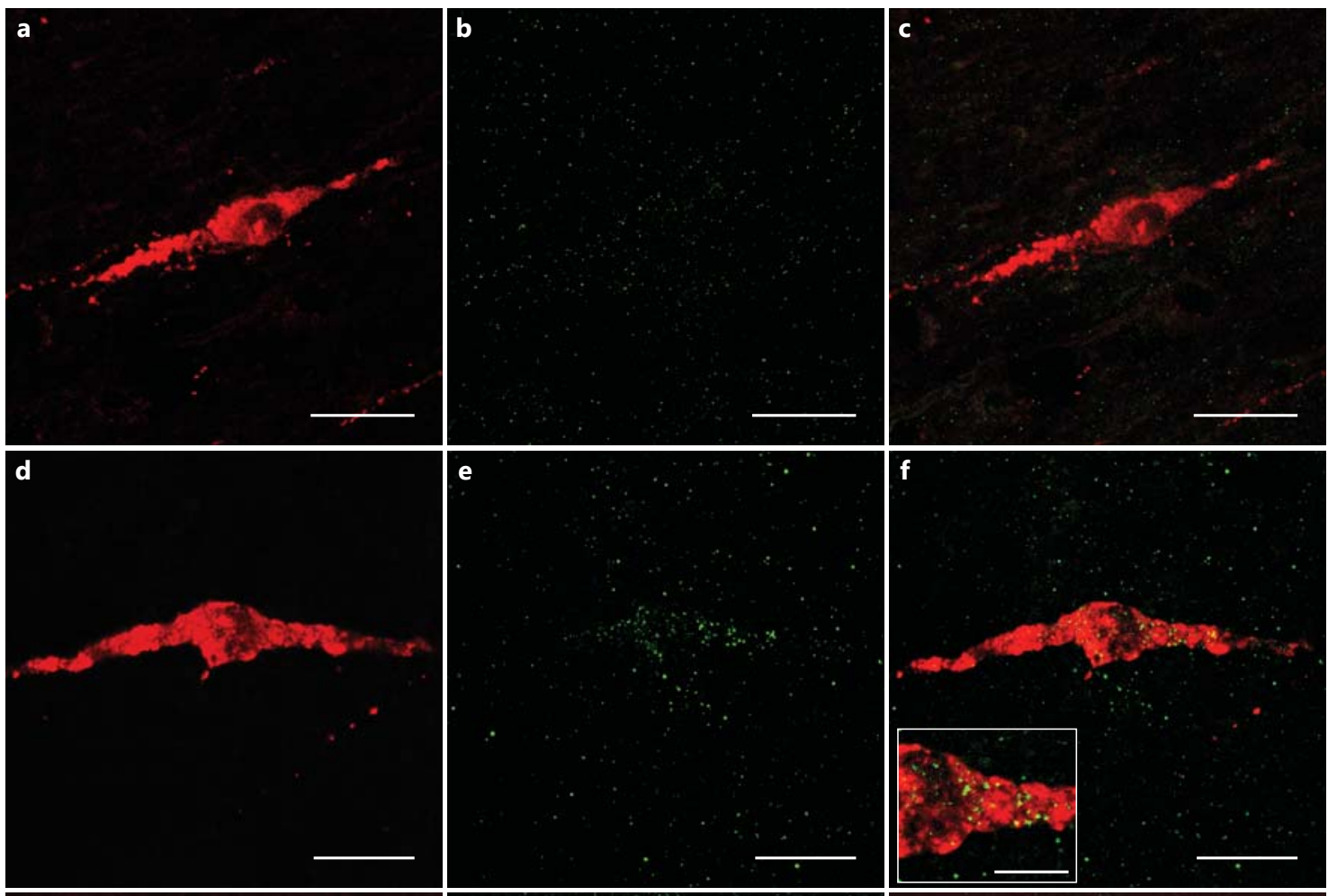

f
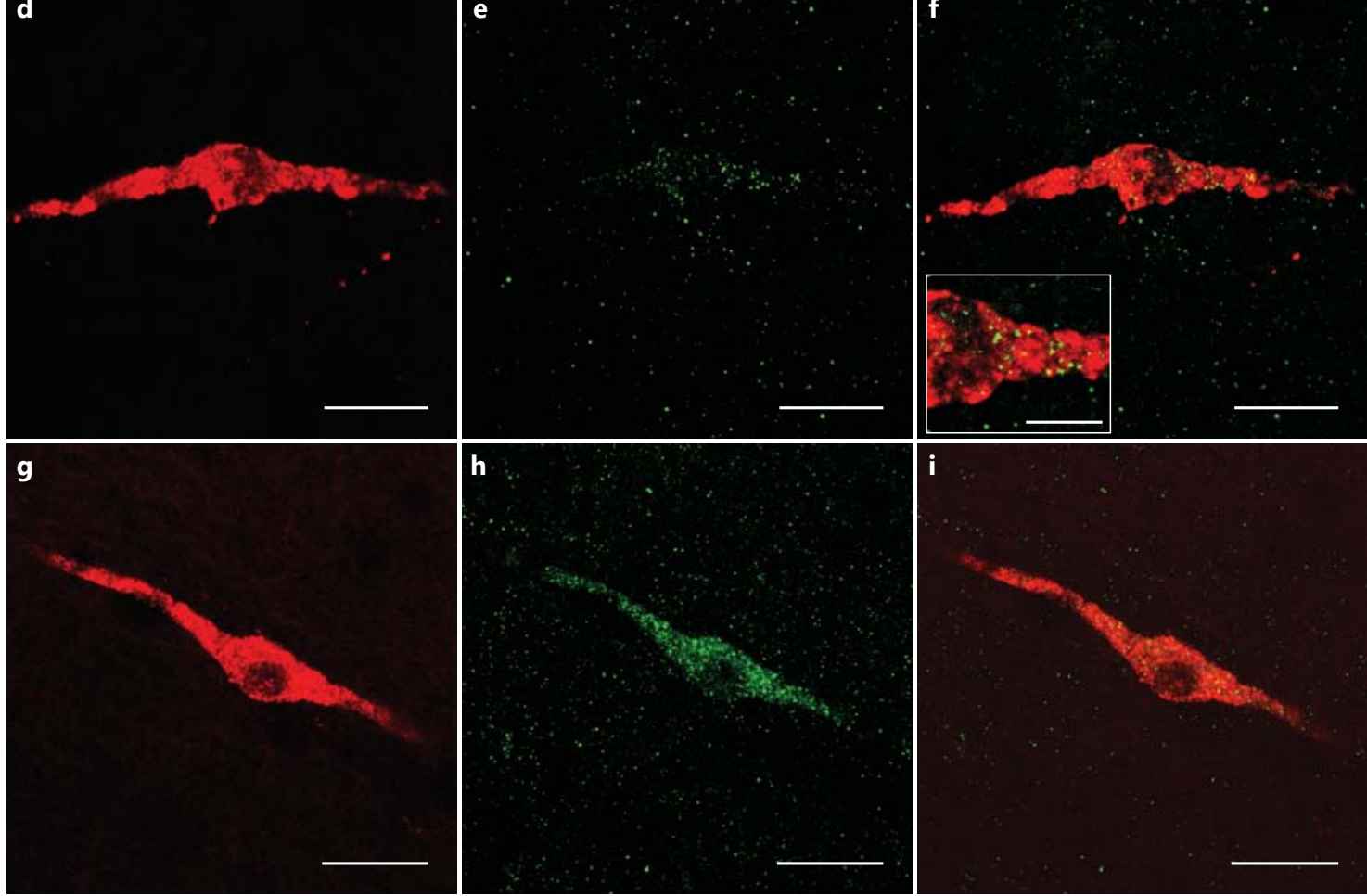

Fig. 1. Photomicrographs of GnRH-IR (a, d, g), GPER-IR ( $\mathbf{b}, \mathbf{e}, \mathbf{h})$, and double-labeling (c, f, i). Representative micrographs of the categories of GPER (green) expression within GnRH neurons (red) are shown for no labeling (a-c), moderate/punctate GPER labeling within GnRH perikarya (d-f), and heavy cytoplasmic double-labeling (g-i). Inset Punctate GPER-IR at high magnification. Scale bars $=25 \mu \mathrm{m}$ (a-i) and $10 \mu \mathrm{m}$ (inset).

a high-resolution image stack of the internal and external zones of 1-2 ME sections (depending on tissue availability) for each animal.

\section{Analysis and Statistics}

All perikarya (table 1) were analyzed with Fiji software [48], and MatLab software (version R2013a; MathWorks, Natick, Mass., USA) was additionally used for calculating the percentage of colocalized puncta in the ME. We used two methods in concert to categorize the immunoreactivity of the perikarya, both the traditional pseudocolored merge of the two channels and a gray-scale analysis to control for any optical illusions due to color perception bias. This was done with an image calculator plug-in in Fiji that creates a single gray-scale image showing the minimum intensity for each pixel of the two channels (i.e. if there is no co-localization, then the minimum intensity is black). We rated the amount of GPER-IR from 1 to 6 in each GnRH-IR perikaryon with both methods and rescored a random subset of the images to ensure consistency. The scores from the two categorization methods were compared, resulting in three categories: no GPER-IR, moderate/ punctate co-localization, and heavy co-localization. 
Fig. 2. Percentage of GnRH perikarya that express GPER (GnRH+/GPER+) and the subset of those double-labeled cells that have heavy cytoplasmic labeling. a Average percentage $( \pm$ SEM $)$ of $\mathrm{GnRH}+/ \mathrm{GPER}+$ perikarya throughout the entire $\mathrm{MBH}$ for young (white bars) and aged monkeys (black bars). b Percentage of $\mathrm{GnRH}+$ / GPER+ cells with either moderate/punctate (top/solid) or heavy cytoplasmic GPER-IR (bottom/striped) for each group. There were no significant effects of age or treatment of the total percentage or type of double-labeling.

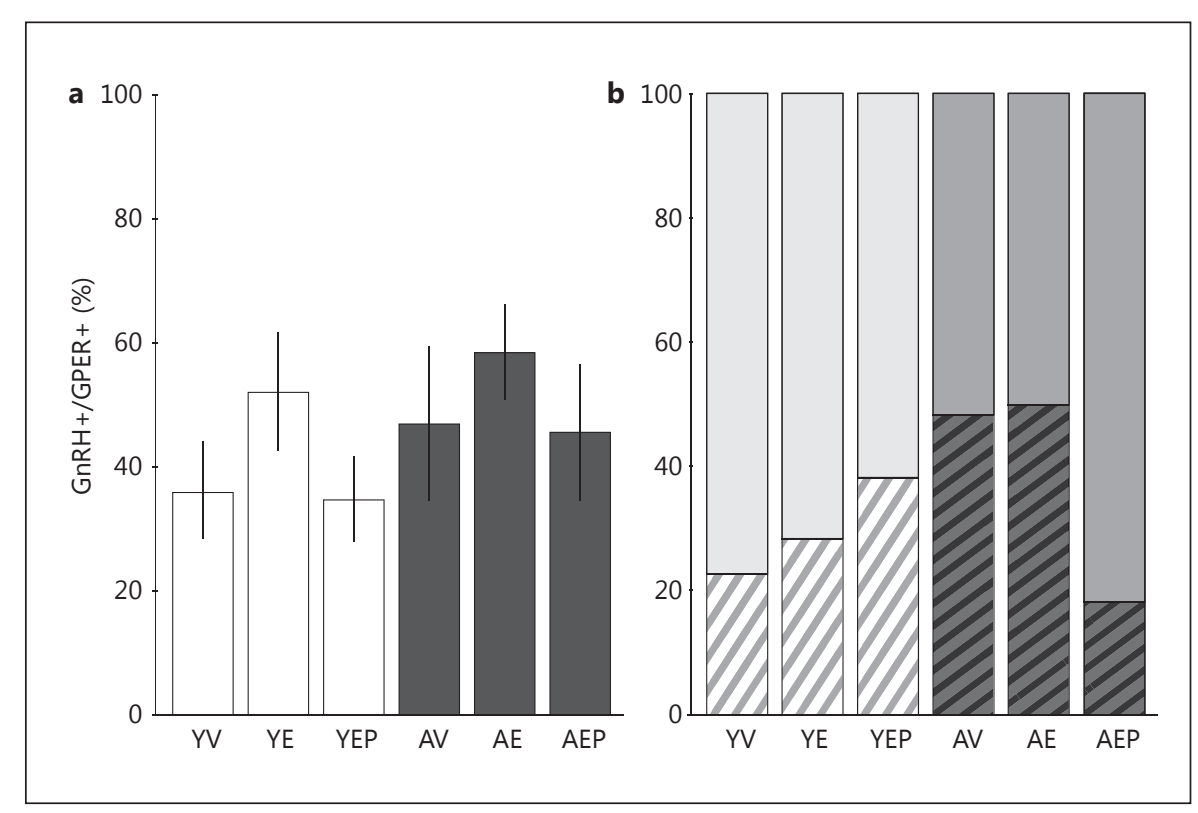

We used the R statistical packages (R Development Core Team, 2012) for all statistical analyses. Kruskal-Wallis (p) nonparametric tests were used because our dataset failed the assumptions of normality, as determined by the Shapiro-Wilks normality and Levene's equality of variance tests. Our alpha level was set to determine significant main effects $(\mathrm{p} \leq 0.05)$ or trends $(0.05<\mathrm{p}<0.10)$. Kruskal-Wallis test was followed by a pairwise Wilcoxon post hoc test to identify specific interactions $[49,50]$.

\section{Results}

\section{GnRH Perikarya in the MBH Co-Express GPER}

Examples of $\mathrm{GnRH}$ perikarya in the $\mathrm{MBH}$ that did or did not co-express GPER are shown in figure 1. GnRH neurons in the 6 groups of monkeys (YV, YE, YEP, AV, $\mathrm{AE}$, and AEP) had the characteristic morphology of bipolar or unipolar perikarya with large nuclei and were scattered through the basal hypothalamus. No significant main effects of age or hormone treatment were found for the morphology or average number of GnRH neurons per section (data not shown). For double-labeling, about half of the GnRH-IR neurons expressed GPER, regardless of age or hormone treatment (fig. 2a). Labeling of GPER in the GnRH neurons was variable, with some GnRH cells showing punctate or moderately intense labeling and others with very heavy labeling throughout the cytoplasm and into the varicosities (fig. 1,3). Additionally, we observed many GPER-IR processes in close contact with $\mathrm{GnRH}$ perikarya and/or proximal processes (fig. 3). Dur- ing analysis, we noticed great variability in the intensity of GPER immunolabeling in GnRH neurons. Therefore, we further subdivided double-labeled GnRH cells qualitatively into moderate/punctate or heavy GPER co-localization. There were no significant effects of age or treatment on the percentage or type of double-labeled GnRH+/ GPER+ neurons (fig. 2b).

The distribution of GnRH neurons that were singlelabeled (GnRH+/GPER-) or double-labeled (GnRH+/ GPER+) was mapped onto representations of the $\mathrm{MBH}$ from rostral to caudal separately for the 6 groups (fig. 4). The mean percentage of co-localized neurons was also calculated across the three regions (fig. 5). In the medial $\mathrm{MBH}$, there was a trend for an effect of age $(\mathrm{p}=0.08)$, with aged animals tending to have a higher percentage of $\mathrm{GnRH}+/ \mathrm{GPER}+$ neurons than the young groups. In the caudal MBH there were trends for effects of both age and treatment ( $\mathrm{p}=0.06$ and $\mathrm{p}=0.09$, respectively).

\section{GnRH Fibers Have Low Co-Expression of GPER in the $M E$}

Both GnRH and GPER were detectable as punctate labeling in the ME (fig. 6). Co-localization of GPER in $\mathrm{GnRH}+$ neural puncta was quantified separately in the internal and external zones of the ME. In both regions there was an average of $12 \%$ co-localization of GnRH-IR and GPER-IR puncta. There were no significant effects of age or treatment (fig. 7). 
$\mathrm{GnRH}$
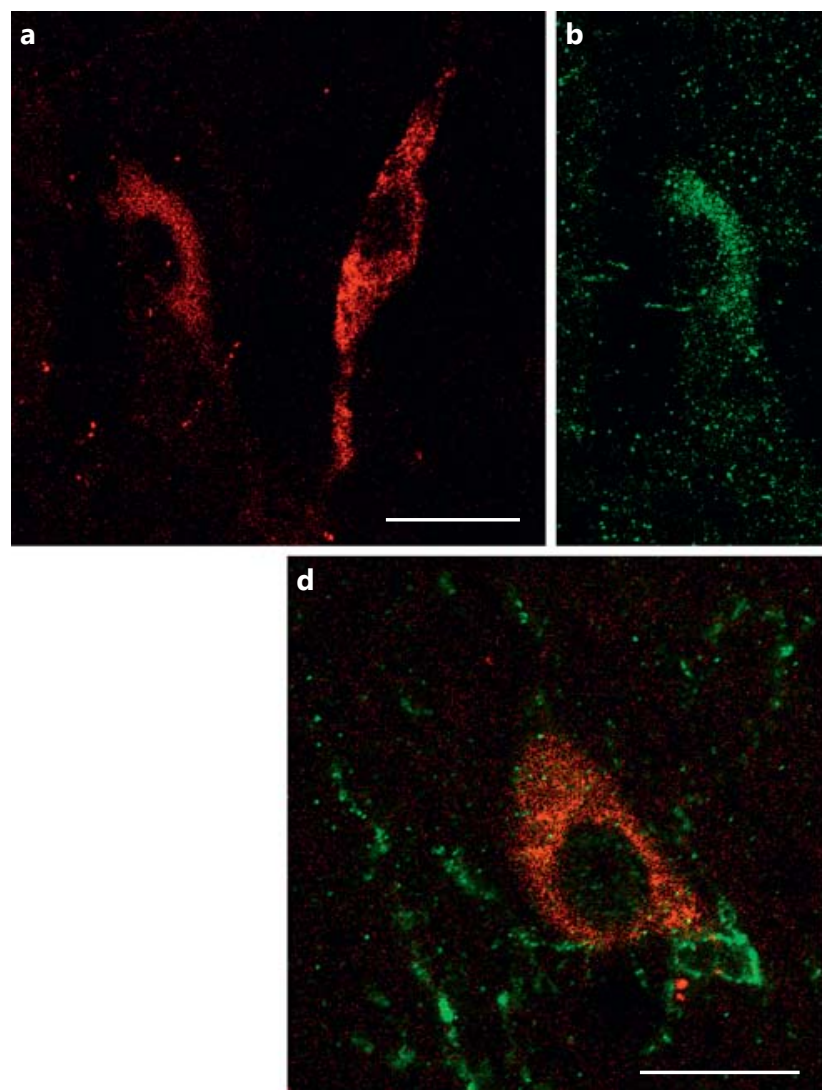

GPER
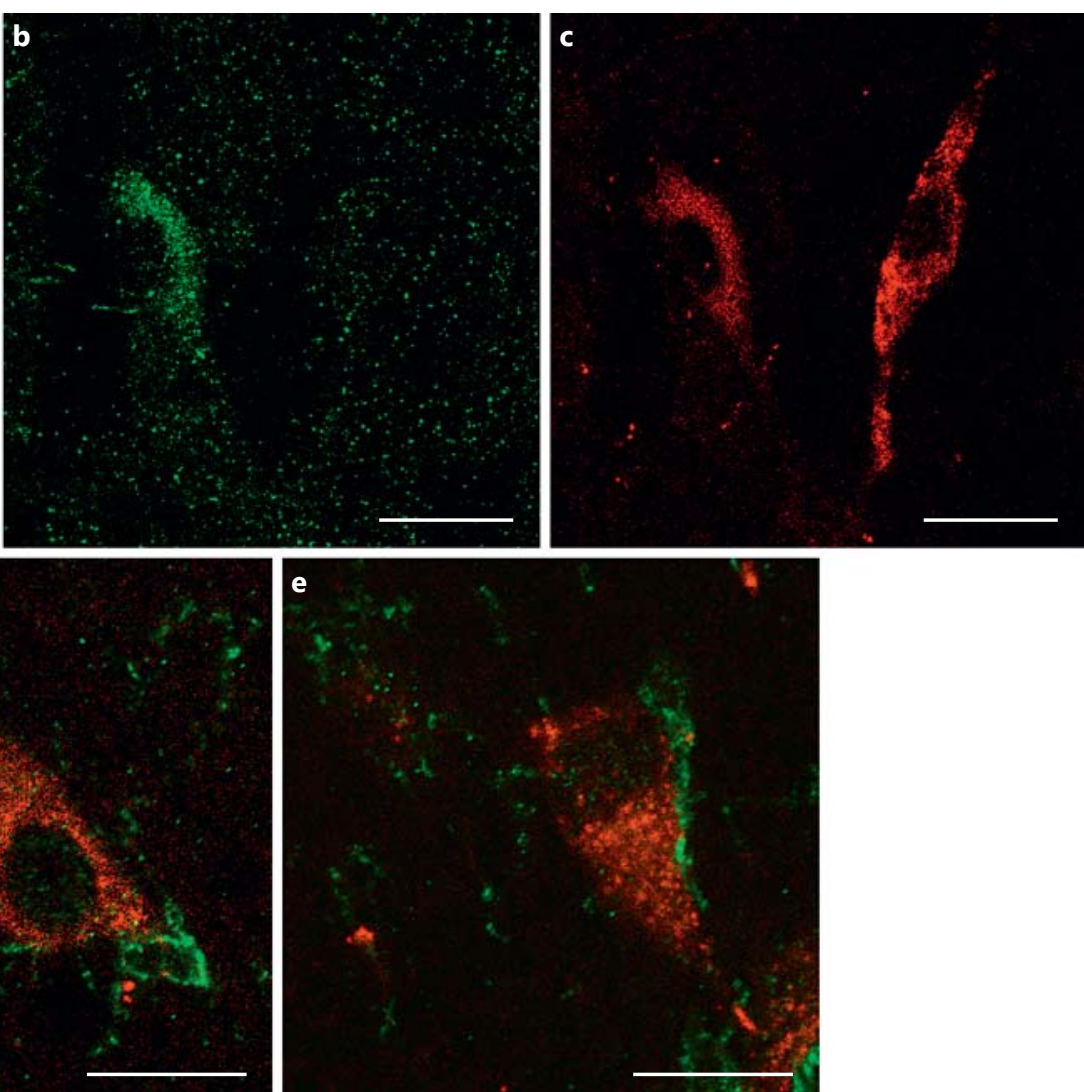

Fig. 3. Photomicrographs of double-labeling of GnRH perikarya and the proximity between GPER processes and GnRH neurons. a-c Two GnRH neurons, one heavily co-localized with GPER (left) next to one that is not labeled with GPER (right). d, e Examples of GnRH perikarya (red) that are in direct contact with GPER-IR processes (green). Scale bars $=35 \mu \mathrm{m}(\mathbf{a}-\mathbf{c})$ and $15 \mu \mathrm{m}(\mathbf{d}, \mathbf{e})$.

\section{Discussion}

The goal of the current work was to add to the limited knowledge about the expression of GPER, a membrane ER, on hypophysiotropic GnRH neurons. We sought to gain novel insights into whether estrogenic regulation may occur directly on GnRH neurons through co-expression, or indirectly via appositions, in a nonhuman primate model. Prior work, mainly conducted ex vivo, has largely supported the possibility of co-expression, but few studies have investigated this relationship in a physiological system. Our current data add three novel pieces of information. First, we ascertained that GnRH cells co-express GPER in adult rhesus monkeys; second, we determined the localization of this co-expression on cell bodies and processes/terminals in the ME, and third, we investigated whether aging and long-term hormone treatments affected co-expression in a clinically relevant rhesus macaque model of menopause.

\section{GnRH Perikarya Co-Express GPER}

The expression of GPER in the brain, including the hypothalamus, is quite abundant in primates and rodents, though there have been few studies that have examined GPER in GnRH neurons [28, 51-54]. Here, using hypothalami from OVX monkeys of two ages under three different hormone treatments, we found that approximately half of the $\mathrm{GnRH}$ perikarya in the $\mathrm{MBH}$ were GPER-IR. Although there were some trends for effects of age and hormone treatment, none were robust, suggest- 


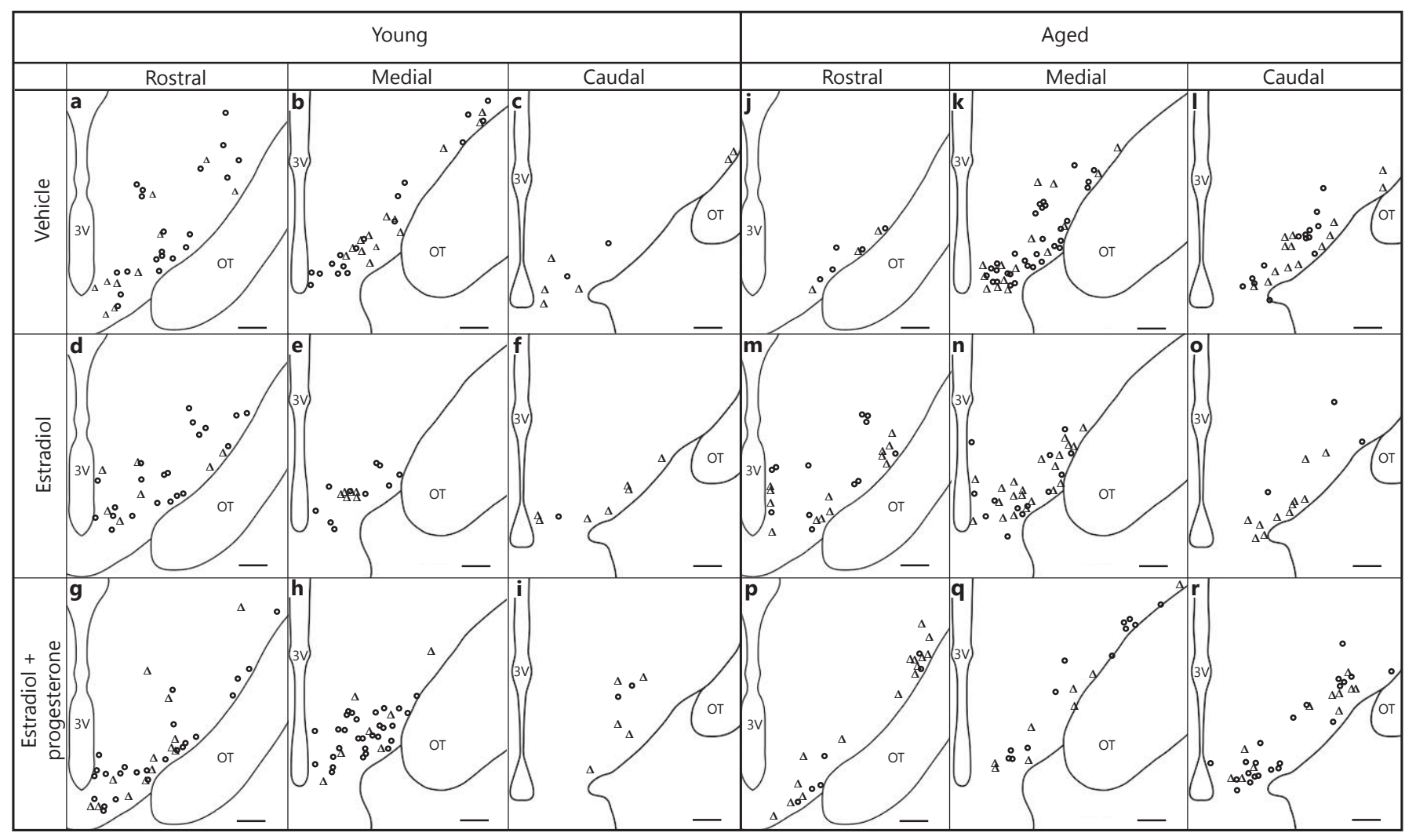

Fig. 4. Distribution of GnRH neurons in the MBH. GnRH neurons were mapped onto a representation of coronal sections of the MBH from rostral [young $(\mathbf{a}, \mathbf{d}, \mathbf{g})$; aged $(\mathbf{j}, \mathbf{m}, \mathbf{p})$ ], medial [young $(\mathbf{b}, \mathbf{e}, \mathbf{h})$; aged $(\mathbf{k}, \mathbf{n}, \mathbf{q})$ ], and caudal regions [young $(\mathbf{c}, \mathbf{f}, \mathbf{i})$; aged $(\mathbf{I}, \mathbf{o}, \mathbf{r})$ ] in young (left) and aged adult rhesus monkeys (right) of the three hormone treatment groups. $\triangle=$ GnRH+/GPER+ double-labeled perikarya; $\mathrm{O}=\mathrm{GnRH}+/ \mathrm{GPER}$ - perikarya. The third ventricle $(3 \mathrm{~V})$ and optic tract $(\mathrm{OT})$ are labeled for orientation. Scale bars $=350 \mu \mathrm{m}$.

ing that co-localization of GPER in GnRH neurons of adult female monkeys is a stable part of the GnRH phenotype. All of the studies that have examined GPER in the context of primate $\mathrm{GnRH}$ neurons support co-localization, but results in rodents are inconsistent. More specifically, cultured embryonic monkey GnRH neurons and GnRH GT1-7 cell lines co-express GPER [21, 23, 27]. In mice, Sun et al. [19] reported that about one third of GnRH neurons were electrophysiologically activated by the GPER agonist G1. However, conflicting results were found by Romanò et al. [55], who did not detect rapid responses to G1 in any of the 7 mouse GnRH neurons examined. There may be species differences in the estrogenic regulation of GnRH via GPER. Additionally, alternate pathways, involving the classic receptors ER- $\alpha$ and ER- $\beta$ that mediate rapid $E_{2}$ activation of $\mathrm{GnRH}$, have been found in mice that are not present in primates [19, $21,23,25,55-57]$. For example, Abrahám et al. [25] discovered that ER- $\beta$ induced CREB phosphorylation in the
GnRH neurons, and Romanò et al. [55] found an ER-adependent pathway involving the GABAergic modulation of $\mathrm{GnRH} \mathrm{Ca}^{2+}$ dynamics, while rapid $\mathrm{E}_{2}$ activation of primate $\mathrm{GnRH}$ neurons can occur independently of either of these classic ERs $[20,21]$. Thus, the role that these ERs play in the regulation of GnRH in primates likely differs from that in rodents, and further research is merited to resolve these differences.

The functional role of GPER in GnRH neurons is not known, although it has been suggested that it may mediate some aspects of hormone feedback and/or synchronization required for pulsatile release [58]. The lack of an obvious reproductive phenotype of GPER knockout mice may have hindered research in this area, as the global knockout may lead to developmental compensation for physiological roles normally mediated by GPER and because, as discussed above, the role of GPER may be different in primates $[18,22,59,60]$. There are still substantial gaps in knowledge about the receptors that mediate posi- 


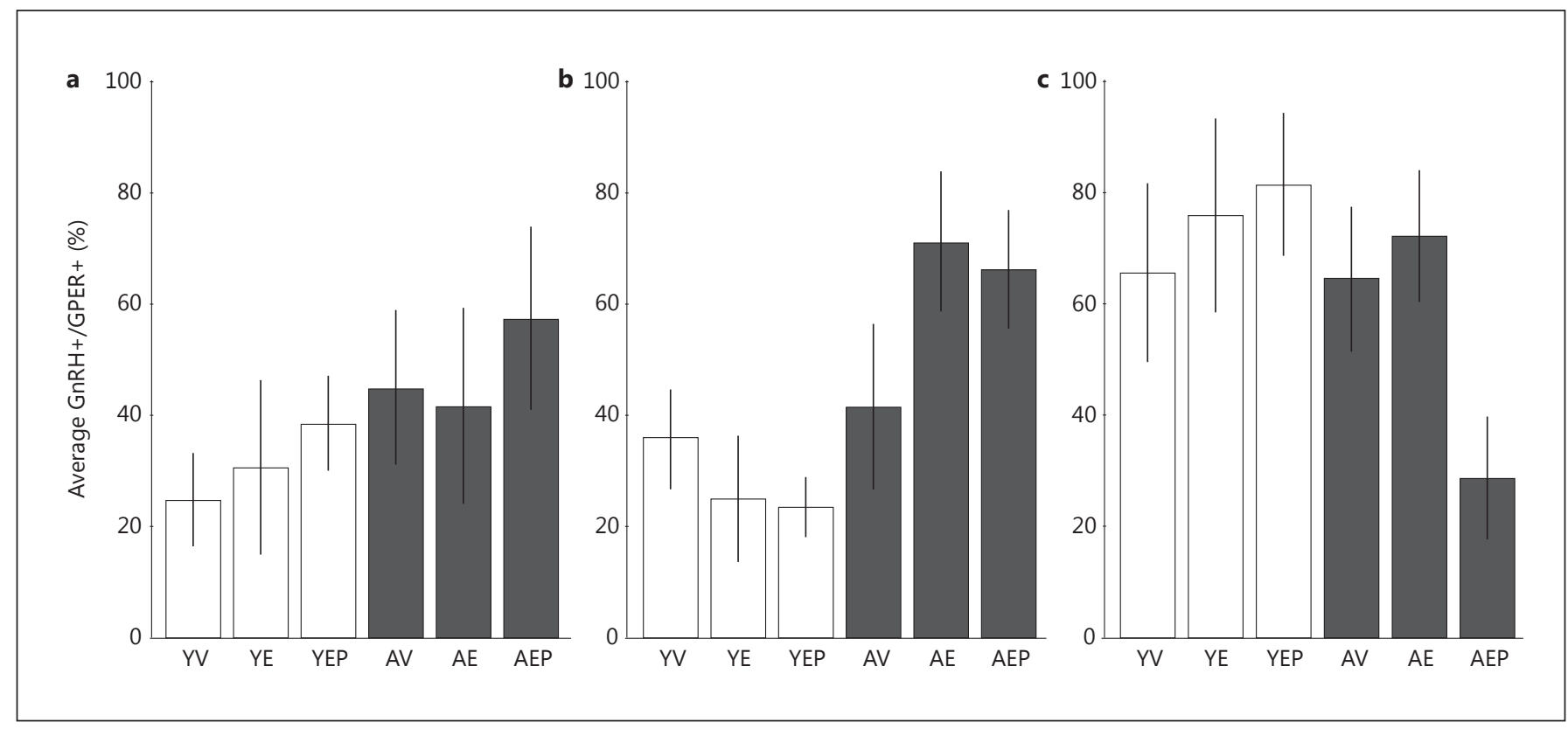

Fig. 5. Distribution of GnRH+/GPER+ cells in the MBH. These graphs show the average percentage $( \pm S E M)$ of GnRH $+/ G P E R+$ perikarya in the rostral (a), medial (b), and caudal $\mathrm{MBH}(\mathbf{c})$. There were trends of age effects in the medial and caudal regions $(\mathrm{p}=0.08$ and $\mathrm{p}=0.06$, respectively) as well as a treatment effect in the caudal $\mathrm{MBH}(\mathrm{p}=0.09)$.
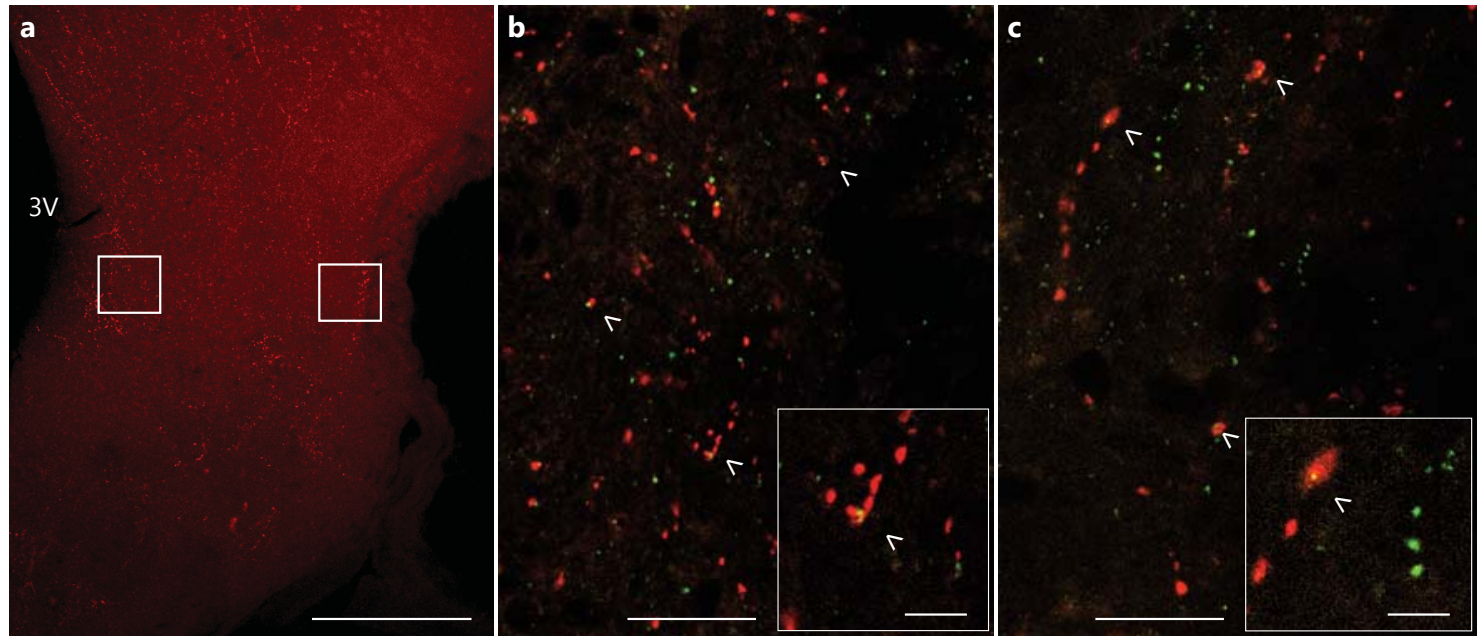

Fig. 6. Representative micrographs of GnRH and GPER immunolabeling in the ME. a Low-magnification image of GnRH-IR in a coronal section through the ME with boxes around the regions of the internal (left) and external zones (right) that were analyzed. The third ventricle $(3 \mathrm{~V})$ is labeled for orientation. High-magnification micrographs of punctate GnRH-IR (red) and GPER-IR (green) are shown in the internal (b) and external zones (c) of the ME. Co-localized puncta (yellow) are indicated with arrowheads. Insets High-magnification examples of colocalization in each region. Scale bars $=350 \mu \mathrm{m}(\mathbf{a}), 20 \mu \mathrm{m}(\mathbf{b}, \mathbf{c})$, and $5 \mu \mathrm{m}$ (insets). 
Fig. 7. Percentage of co-localization of GnRH+/GPER+ puncta in the ME. The mean percentage $( \pm$ SEM) of GnRH puncta that were co-localized with GPER-IR in the internal (a) and external ME (b) are shown for each group. There were no significant effects of age or treatment in either region.

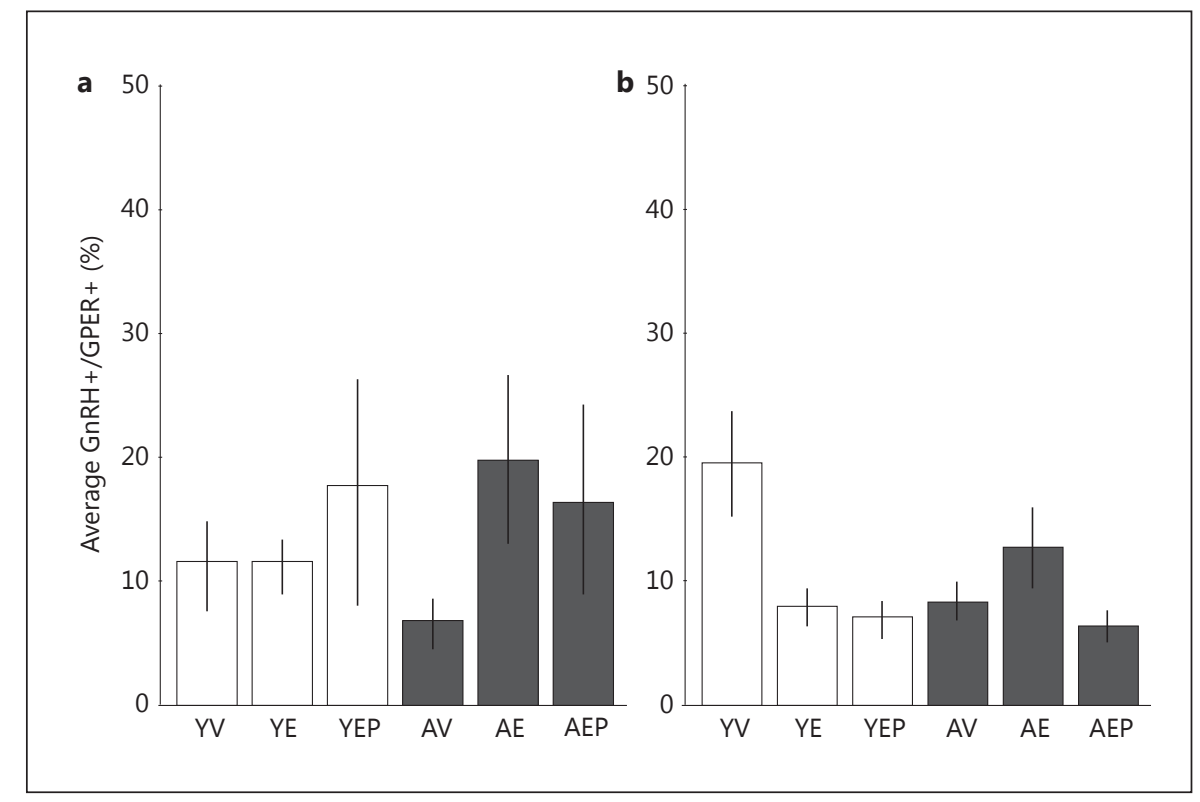

tive and negative effects of estrogens on GnRH neurons, making the GPER of potential interest beyond ER- $\alpha$, ER$\beta$, and STX-sensitive receptors $[22,57,61]$. Although at the time the experiments were conducted it was not possible to perform pharmacological work on our monkeys, future work should investigate effects of $E_{2}$ action on $\mathrm{GnRH}$ neurons in the presence of agonists or antagonists to GPER.

\section{The Relationship between GnRH Perikarya and GPER} Is Highly Heterogeneous

Our analyses revealed that the intensity and pattern of GPER-IR varied between individual GnRH neurons: some cells had exclusively punctate and sparse labeling, while others had GPER-IR distributed densely and evenly throughout the cell. Many of the labeled GnRH perikarya in these monkeys showed GPER labeling in proximal processes and, in a few cases, more distal from the GnRH soma. Consistent with our results, GPER has been found in multiple intracellular compartments, including mitochondrial membranes [62], the endoplasmic reticulum and Golgi apparatus $[63,64]$, near the nucleus [64, $65]$, throughout the cytoplasm $[51,53,62]$, as well as on the cell membrane $[23,28,51,62,65]$, in a tissue and species-specific manner. The physiological roles that these compartmental differences may play are currently unknown.

Some GnRH neurons, while not double-labeled, were found in very close association with GPER-IR varicosi- ties. In many cases, the GPER-IR processes appeared to wrap around GnRH soma, proximal dendrites, or axons. Electron microscopy would be needed to verify whether or not these closely apposed cells have synapses or gap junctions, but if that were the case, then GPER+ cells may also mediate effects of $\mathrm{E}_{2}$ indirectly onto the $\mathrm{GnRH}$ neurons they contact. These GPER-IR processes could arise from cells that are either neuronal or glial, as GPER has been found in both types of cells in the regions near $\mathrm{GnRH}$ perikarya [62]. Together, these results of co-expression and close proximity to GnRH suggest that GPER could potentially mediate both direct and indirect $\mathrm{E}_{2}$ regulation of GnRH neural activity at or near the soma.

We found some regional specificity in the rostral-tocaudal distribution of $\mathrm{GnRH}+/ \mathrm{GPER}+$ neurons. In young monkeys, more GnRH neurons were detected in the rostral and medial $\mathrm{MBH}$, while in aged animals, they were located more mediocaudally. Due to limitations in the numbers of animals and tissues, we do not want to overinterpret these data. Nevertheless, consistent with our results, age-related changes in the distribution of GnRH cells in rodents have been reported $[44,66]$. Rubin and King [66] found that there was an increase in GnRH neurons in the dorsomedial portion of the preoptic area of young rats preceding the luteinizing hormone surge, and this was not observed in middle-aged animals. Additionally, Miller and Gore [44] found that there were fewer GnRH neurons in the medial septum of middleaged irregular and acyclic rats than in young or regularly 
cycling rats. Together these studies suggest that the distribution of GnRH-IR perikarya may be responsive to the hormonal milieu, and age-related alterations in the dynamics of this system may be linked to reproductive senescence in rodents. While the differences in distribution that we measured did not reach significance, the results found here are suggestive of the possibility that monkeys also undergo age-related reorganization of $\mathrm{GnRH}$ perikarya.

We did not find any obvious change in GnRH cell numbers, consistent with observations in monkeys, mice, and rats $[44,46,67,68]$. Although a few other studies have found some age-related changes in the number of $\mathrm{GnRH}$ neurons in aged rats and mice, these were relatively small effects $[66,69]$. Thus, the literature as a whole suggests small to no changes in GnRH perikaryon numbers with aging but possible distributional changes.

\section{GnRH Terminals in the ME Have Low Co-Expression of GPER}

The ME is an important site of GnRH regulation [7072]. The external zone of the ME contains the portal capillary bed, has a high density of secretory neuroterminals and tanycytic end feet, and is the location of GnRH release. The internal zone of the ME contains GnRH processes and the cell bodies of tanycytes, specialized glial cells that form a selective barrier to the portal capillaries $[70,73,74]$. Age-related changes to GnRH release measured in the ME have been reported in rodents, in which its release was decreased, and in monkeys, in which $\mathrm{GnRH}$ pulses (especially amplitudes) were increased [29, 75]. The ME region undergoes dramatic cytoarchitectural and phenotypic changes with reproductive aging and hormone treatment in rats, especially around the terminals and capillaries, which directly affect the release of $\mathrm{GnRH}$ [70-74, 76-78]. Species-related differences in GnRH release are, in part, attributable to feedback regulatory differences with aging, underscoring the importance of conducting this research in a nonhuman primate model.

In the current study, we found similar amounts of colocalization of GPER and GnRH in the internal and external zones of the ME, with no age or treatment effects. There was a much lower percentage of co-localization in the ME ( 12\%) than in the perikarya of GnRH neurons $(\sim 50 \%)$. There are several interpretations for these differences between cell compartments that are not mutually exclusive. GnRH perikarya may transport only a small percentage of synthesized GPER along the axon to the nerve terminals and processes in the ME. Alternatively, or in addition, the detectability of GPER in the ME may

Monkey GnRH Neurons Co-Express GPER be below the threshold of sensitivity of confocal microscopy, which is an issue that would require electron microscopy to resolve. Confirming our finding of GPER in monkey ME, a recent study conducted by our laboratory on a model of natural reproductive aging in the rat also showed that GPER mRNA is detectable in the microdissected ME (including both internal and external zones) [79]. Furthermore, in that rat study, GPER mRNA expression was positively correlated with the genes for ER- $\alpha$, TGF- $\alpha$, prodynorphin, the vitamin $\mathrm{D}$ receptor, and the $\mathrm{P}_{4}$ receptor and was negatively correlated with the $\mathrm{GABA}_{\mathrm{B} 2}$ receptor. While follow-up work is needed to further study any functional relationships, these data suggest some interesting molecular candidates for a regulatory network of GnRH in the ME, among which is GPER.

\section{Summary and Limitations}

In this study conducted in young and aged OVX rhesus macaques, about half of the GnRH perikarya expressed GPER, whereas a smaller percentage of processes and terminals (12\%) had co-expression in the ME. GnRH cell bodies and processes were often in close apposition or proximity to GPER-IR elements. These data add new information about the robust presence of GPER in and around GnRH cells and suggest a viable site of direct action of estrogens on the GnRH system. Additionally, aging and hormone treatments had limited effects on the co-expression of GnRH and GPER in this rhesus monkey model of menopause. This latter result underscores the stability of GnRH neurons across adult development and into aging.

As is often the case with studies of nonhuman primates, we had a number of experimental constraints. The number of animals that were available for this experiment, and the sometimes poor quality of tissues, limited the statistical power. In addition, there are both strengths and weaknesses to the OVX with/without hormone treatment model. While substantial numbers of women undergo surgical menopause, by far the majority of women undergo a natural menopause, involving a more gradual loss of ovarian hormones. It was not possible to utilize monkeys with intact ovaries for the current study as rhesus macaques undergo reproductive senescence very late in life [30] and such elderly monkeys were not attainable.

However, we would also like to underscore some advantages of our model. Our young and aged monkeys corresponded roughly to young adult ( 30 -year-old) and middle-aged adult ( $~ 50$-year-old) women. Thus, the work was conducted in age-appropriate animals in terms of 
chronological age. In addition, as a primary goal was to gain insights into how hormone treatments affect neurobiological responses, the hormone deprivation or replacement models enabled us to directly address this point not only in our study but in our collaborators' laboratories, who also utilized these valuable brain tissues [32-39]. In ongoing work, we are delving further into additional, biomedically relevant models of the timing and duration of hormone replacement relative to deprivation in a test of the 'critical window' hypothesis of menopause [6].

\section{Acknowledgments}

We are grateful to Dr. Jeffrey Roberts and Mary Roberts at the California National Primate Research Center UC - Davis Primate Center for expert care of the animals. Dr. John H. Morrison and William Janssen are acknowledged for monkey work and perfusions. Dr. Weiling Yin and Megan Noel assisted with the preparation and sectioning of hypothalamic tissues. Julie Hayes' expert advice on the confocal microscope was essential for the success of this project. Dr. Ed Filardo and Henryk Urbanski provided muchneeded antibodies for GPER and GnRH, respectively. The study was supported by NIH grant PO1 AG16765.

\section{References}

1 Avis NE, Brambilla D, McKinlay SM, Vass K: 12 Gore AC: Gonadotropin-releasing hormone A longitudinal analysis of the association between menopause and depression: results from the Massachusetts Women's Health Study. Ann Epidemiol 1994;4:214-220.

-2 Avis NE, Brockwell S, Randolph JF Jr, Shen S, Cain VS, Ory M, Greendale GA: Longitudinal changes in sexual functioning as women transition through menopause: results from the Study of Women's Health Across the Nation. Menopause 2009;16:442-452.

3 Hall JE: Neuroendocrine physiology of the early and late menopause. Endocrinol Metab Clin North Am 2004;33:637-659.

4 McEwen BS: Estrogen actions throughout the brain. Recent Prog Horm Res 2002;57:357384.

$>5$ Cauley JA, Robbins J, Chen Z, Cummings SR, Jackson RD, LaCroix AZ, LeBoff M, Lewis CE, McGowan J, Neuner J, Pettinger M, Stefanick ML, Wactawski-Wende J, Watts NB: Effects of estrogen plus progestin on risk of fracture and bone mineral density. JAMA 2014;290: 1729-1738.

6 Maki PM: Critical window hypothesis of hormone therapy and cognition: a scientific update on clinical studies. Menopause 2013;20: 695-709.

7 Kim JK, Alley D, Hu P, Karlamangla A, Seeman T, Crimmins EM: Changes in postmenopausal hormone therapy use since 1988 . Womens Health Issues 2007;17:338-341.

$>8$ Panay N, Fenton A: The WHI: have our worst fears come true? Climacteric 2013;16:507508.

$\checkmark 9$ Yoon B, Nyirjesy I, Billingsley FS: WHIMS trial: letter to the editors. JAMA 2003;290: 1707.

10 Gass M: Highlights from the latest WHI publications and the latest North American Menopause Society position statement on use of menopausal hormone therapy. Cleve Clin J Med 2008;75(suppl 4):S13-S16.

$>11$ Lobo RA: Where are we 10 years after the Women's Health Initiative? J Clin Endocrinol Metab 2013;98:1771-1780.
$(\mathrm{GnRH})$ neurons: gene expression and neuroanatomical studies. Prog Brain Res 2002;141: 193-208.

13 King JC, Anthony EL: LHRH neurons and their projections in humans and other mammals: species comparisons. Peptides 1984;5: 195-207.

14 Rangaraju NS, Xu JF, Harris RB: Pro-gonadotropin-releasing hormone protein is processed within hypothalamic neurosecretory granules. Neuroendocrinology 1991;53:20 28. underlying the pubertal increase in LHRH release in the rhesus monkey. Trends Endocrinol Metab 2001;12:353-359.

16 Sisk CL, Foster DL: The neural basis of puberty and adolescence. Nat Neurosci 2004;7: 1040-1047.

17 Sullivan KA, Witkin JW, Ferin M, Silverman AJ: Gonadotropin-releasing hormone neurons in the rhesus macaque are not immunoreactive for the estrogen receptor. Brain Res 1995;685:198-200.

18 Zhang C, Kelly MJ, Rønnekleiv OK: $17 \beta$-Estradiol rapidly increases ATP-sensitive potassium channel activity in gonadotropinreleasing hormone neurons [corrected] via a protein kinase signaling pathway. Endocrinology 2010;151:4477-4484.

19 Sun J, Chu Z, Moenter SM: Diurnal in vivo and rapid in vitro effects of estradiol on voltage-gated calcium channels in gonadotropinreleasing hormone neurons. J Neurosci 2010; 30:3912-3923.

20 Abe H, Keen KL, Terasawa E: Rapid action of estrogens on intracellular calcium oscillations in primate luteinizing hormone-releasing hormone-1 neurons. Endocrinology 2008; 149:1155-1162.

21 Kenealy BP, Keen KL, Terasawa E: Rapid action of estradiol in primate $\mathrm{GnRH}$ neurons: the role of estrogen receptor alpha and estrogen receptor beta. Steroids 2011;76:861-866.
15 Richter TA, Terasawa E: Neural mechanisms
22 Kenealy BP, Keen KL, Rønnekleiv OK, Terasawa E: STX, a novel nonsteroidal estrogenic compound, induces rapid action in primate GnRH neuronal calcium dynamics and peptide release. Endocrinology 2011;152:31823191.

23 Noel SD, Keen KL, Baumann DI, Filardo EJ, Terasawa E: Involvement of $\mathrm{G}$ protein-coupled receptor 30 (GPR30) in rapid action of estrogen in primate LHRH neurons. Mol Endocrinol 2009;23:349-359.

24 Abe H, Terasawa E: Firing pattern and rapid modulation of activity by estrogen in primate luteinizing hormone releasing hormone-1 neurons. Endocrinology 2005; 146:43124320.

25 Abrahám IM, Han SK, Todman MG, Korach KS, Herbison AE: Estrogen receptor beta mediates rapid estrogen actions on gonadotropin-releasing hormone neurons in vivo. J Neurosci 2003;23:5771-5777.

26 Hrabovszky E, Kalló I, Szlávik N, Keller E, Merchenthaler I, Liposits Z: Gonadotropinreleasing hormone neurons express estrogen receptor- $\beta$. J Clin Endocrinol Metab 2007;92: 2827-2830.

27 Jacobi JS, Martin C, Nava G, Jeziorski MC, Clapp C, Martinez de al Escalera G: 17-Betaestradiol directly regulates the expression of adrenergic receptors and kisspeptin/GPR54 system in GT1-7 GnRH neurons. Neuroendocrinology 2007;86:260-269.

28 Naugle MM, Nguyen LT, Merceron TK, Filardo E, Janssen WG, Morrison JH, Rapp PR, Gore AC: G-protein coupled estrogen receptor, estrogen receptor $\alpha$, and progesterone receptor immunohistochemistry in the hypothalamus of aging female rhesus macaques given long-term estradiol treatment. J Exp Zool A Ecol Genet Physiol 2014;321:399-414.

$>29$ Gore AC, Windsor-Engnell BM, Terasawa E: Menopausal increases in pulsatile gonadotropin-releasing hormone release in a nonhuman primate (Macaca mulatta). Endocrinology 2004;145:4653-4659. 
-30 Gilardi KV, Shideler SE, Valverde CR, Roberts JA, Lasley BL: Characterization of the onset of menopause in the rhesus macaque. Biol Reprod 1997;57:335-340.

-31 Bachevalier J, Landis LS, Walker LC, Brickson M, Mishkin M, Price DL, Cork LC: Aged monkeys exhibit behavioral deficits indicative of widespread cerebral dysfunction. Neurobiol Aging 1991;12:99-111.

- 32 Hao J, Janssen WG, Tang Y, Roberts JA, McKay H, Lasley B, Allen PB, Greengard P, Rapp PR, Kordower JH, Hof PR, Morrison JH: Estrogen increases the number of spinophilinimmunoreactive spines in the hippocampus of young and aged female rhesus monkeys. J Comp Neurol 2003;465:540-550.

- 33 Hao J, Rapp PR, Leffler AE, Leffler SR, Janssen WG, Lou W, McKay H, Roberts JA, Wearne SL, Hof PR, Morrison JH: Estrogen alters spine number and morphology in prefrontal cortex of aged female rhesus monkeys. J Neurosci 2006;26:2571-2578.

- 34 Hao J, Rapp PR, Janssen WG, Lou W, Lasley $\mathrm{BL}, \mathrm{Hof} \mathrm{PR}$, Morrison JH: Interactive effects of age and estrogen on cognition and pyramidal neurons in monkey prefrontal cortex. Proc Natl Acad Sci USA 2007;104:11465-11470.

- 35 Hara Y, Yuk F, Puri R, Janssen WG, Rapp PR, Morrison JH: Presynaptic mitochondrial morphology in monkey prefrontal cortex correlates with working memory and is improved with estrogen treatment. Proc Natl Acad Sci USA 2014;111:486-491.

-36 Rapp PR, Morrison JH, Roberts JA: Cyclic estrogen replacement improves cognitive function in aged ovariectomized rhesus monkeys. J Neurosci 2003;23:5708-5714.

- 37 Wang AC, Hara Y, Janssen GM, Rapp PR, Morrison JH: Synaptic estrogen receptor- $\alpha$ levels in prefrontal cortex in female rhesus monkeys and their correlation with cognitive performance. J Neurosci 2010;30:1277012776.

- 38 Baxter MG, Roberts MT, Gee NA, Lasley BL, Morrison JH, Rapp PR: Multiple clinically relevant hormone therapy regimens fail to improve cognitive function in aged ovariectomized rhesus monkeys. Neurobiol Aging 2013;34:1882-1890.

- 39 Ohm DT, Bloss EB, Janssen WG, Dietz KC, Wadsworth S, Lou W, Gee NA, Lasley BL, Rapp PR, Morrison JH: Clinically relevant hormone treatments fail to induce spinogenesis in prefrontal cortex of aged female rhesus monkeys. J Neurosci 2012;32:11700-11705.

-40 Filardo EJ, Quinn JA, Bland KI, Frackelton AR Jr: Estrogen-induced activation of Erk-1 and Erk-2 requires the $G$ protein-coupled receptor homolog, GPR30, and occurs via trans-activation of the epidermal growth factor receptor through release of HB-EGF. Mol Endocrinol 2000;14:1649-1660.

-41 Filardo E, Quinn J, Pang Y, Graeber C, Shaw S, Dong J, Thomas P: Activation of the novel estrogen receptor $\mathrm{G}$ protein-coupled receptor 30 (GPR30) at the plasma membrane. Endocrinology 2007;148:3236-3245.
42 Hammond R, Nelson D, Gibbs RB: GPR30 co-localizes with cholinergic neurons in the basal forebrain and enhances potassiumstimulated acetylcholine release in the hippocampus. Psychoneuroendocrinology 2011;36: 182-192.

43 Kermath BA, Riha PD, Sajjad A, Gore AC: Effects of chronic NMDA-NR2b inhibition in the median eminence of the reproductive senescent female rat. J Neuroendocrinol 2013; 25:887-897.

44 Miller BH, Gore AC: N-methyl-D-aspartate receptor subunit expression in GnRH neurons changes during reproductive senescence in the female rat. Endocrinology 2002;143: 3568-3574.

45 Urbanski HF: Monoclonal antibodies to luteinizing hormone-releasing hormone: production, characterization, and immunocytochemical application. Biol Reprod 1991;44:681-686.

46 Witkin JW: Luteinizing hormone releasing hormone (LHRH) neurons in aging female rhesus macaques. Neurobiol Aging 1986;7: 259-263.

47 Goldsmith PC, Song T: The gonadotropinreleasing hormone containing ventral hypothalamic tract in the fetal rhesus monkey (Macaca mulatta). J Comp Neurol 1987;257: 130-139.

48 Schindelin J, Arganda-Carreras I, Frise E, Kaynig V, Longair M, Pietzsch T, Preibisch S, Rueden C, Saalfeld S, Schmid B, Tinevez JY, White DJ, Hartenstein V, Eliceiri K, Tomancak P, Cardona A: Fiji: an open-source platform for biological-image analysis. Nat Methods 2012;9:676-682.

49 Kruskal W, Wallis W: Use of ranks in onecriterion variance analysis. JASA 1952;47: 582-621.

50 Wilcoxon F: Individual comparisons by ranking methods. Biometrics 1945;1:80-83.

51 Brailoiu E, Dun SL, Brailoiu GC, Mizuo K, Sklar LA, Oprea TI, Prossnitz ER, Dun NJ: Distribution and characterization of estrogen receptor $\mathrm{G}$ protein-coupled receptor 30 in the rat central nervous system. J Endocrinol 2007; 193:311-321.

\$2 Canonaco M, Giusi G, Madeo A, Facciolo RM, Lappano R, Canonaco A, Maggiolini M: A sexually dimorphic distribution pattern of the novel estrogen receptor G-protein-coupled receptor 30 in some brain areas of the hamster. J Endocrinol 2008;196:131-138.

53 Hazell GGJ, Yao ST, Roper JA, Prossnitz ER, O'Carroll AM, Lolait SJ: Localisation of GPR30, a novel G protein-coupled oestrogen receptor, suggests multiple functions in rodent brain and peripheral tissues. J Endocrinol 2009;202:223-236.

54 Walker DM, Kirson D, Perez LF, Gore AC: Molecular profiling of postnatal development of the hypothalamus in female and male rats. Biol Reprod 2012;87:129.

55 Romanò N, Lee K, Abrahám IM, Jasoni CL, Herbison AE: Nonclassical estrogen modulation of presynaptic GABA terminals modulates calcium dynamics in gonadotropin- releasing hormone neurons. Endocrinology 2008;149:5335-5344.

56 Chu Z, Andrade J, Shupnik MA, Moenter SM: Differential regulation of gonadotropin-releasing hormone neuron activity and membrane properties by acutely applied estradiol: dependence on dose and estrogen receptor subtype. J Neurosci 2009;29:5616-5627.

57 Cheong RY, Porteous R, Chambon P, Abrahám IM, Herbison AE: Effects of neuron-specific estrogen receptor (ER) $\alpha$ and ER $\beta$ deletion on the acute estrogen negative feedback mechanism in adult female mice. Endocrinology 2014;155:1418-1427.

- 58 Terasawa E, Kenealy BP: Neuroestrogen, rapid action of estradiol, and GnRH neurons. Front Neuroendocrinol 2012;33:364-375.

59 Meyer MR, Amann K, Field AS, Hu C, Hathaway HJ, Kanagy NL, Walker MK, Barton M, Prossnitz ER: Deletion of G protein-coupled estrogen receptor increases endothelial vasoconstriction. Hypertension 2012;59:507-512.

60 Prossnitz ER, Barton M: The G-protein-coupled estrogen receptor GPER in health and disease. Nat Rev Endocrinol 2011;7:715-726.

61 Christian CA, Moenter SM: The neurobiology of preovulatory and estradiol-induced gonadotropin-releasing hormone surges. Endocr Rev 2010;31:544-577.

62 Almey A, Filardo EJ, Milner TA, Brake WG: Estrogen receptors are found in glia and at extranuclear neuronal sites in the dorsal striatum of female rats: evidence for cholinergic but not dopaminergic colocalization. Endocrinology 2012;153:5373-5383.

63 Isensee J, Meoli L, Zazzu V, Nabzdyk C, Witt H, Soewarto D, Effertz K, Fuchs H, GailusDurner V, Busch D, Adler T, Angelis MH, Irgang $M$, Otto $C$, Noppinger PR: Expression pattern of $\mathrm{G}$ protein-coupled receptor 30 in LacZ reporter mice. Endocrinology 2009;150: 1722-1730.

64 Revankar CM, Cimino DF, Sklar LA, Arterburn JB, Prossnitz ER: A transmembrane intracellular estrogen receptor mediates rapid cell signaling. Science 2005;307:1625-1630.

65 Cheng SB, Graeber CT, Quinn JA, Filardo EJ: Retrograde transport of the transmembrane estrogen receptor, G-protein-coupled-receptor-30 (GPR30/GPER) from the plasma membrane towards the nucleus. Steroids 2011;76:892-896.

66 Rubin BS, King JC: The number and distribution of detectable luteinizing hormone (LH)releasing hormone cell bodies changes in association with the preovulatory LH surge in the brains of young but not middle-aged female rats. Endocrinology 1994;134:467-474.

-67 Hoffman GE, Finch CE: LHRH neurons in the female C57BL/6J mouse brain during reproductive aging: no loss up to middle age. Neurobiol Aging 1986;7:45-48.

68 Rubin BS, King JC, Bridges RS: Immunoreactive forms of luteinizing hormone-releasing hormone in the brains of aging rats exhibiting persistent vaginal estrus. Biol Reprod 1984; 31:343-351. 
69 Funabashi T, Kimura F: The number of luteinizing hormone-releasing hormone immunoreactive neurons is significantly decreased in the forebrain of old-aged female rats. Neurosci Lett 1995;189:85-88.

70 King JC, Rubin BS: Dynamic alterations in luteinizing hormone-releasing hormone (LHRH) neuronal cell bodies and terminals of adult rats. Cell Mol Neurobiol 1995;15:89106.

-71 Yin W, Wu D, Noel ML, Gore AC: Gonadotropin-releasing hormone neuroterminals and their microenvironment in the median eminence: effects of aging and estradiol treatment. Endocrinology 2009;150:5498-5508.

-72 Ojeda SR, Lomniczi A, Sandau US: Glial-gonadotrophin hormone $(\mathrm{GnRH})$ neurone interactions in the median eminence and the control of GnRH secretion. J Neuroendocrinol 2008;20:732-742.
73 Rodríguez EM, Blázquez JL, Guerra M: The design of barriers in the hypothalamus allows the median eminence and the arcuate nucleus to enjoy private milieus: the former opens to the portal blood and the latter to the cerebrospinal fluid. Peptides 2010;31:757-776.

74 Yin W, Gore AC: The hypothalamic median eminence and its role in reproductive aging. Ann NY Acad Sci 2010;1204:113-122.

75 Rubin BS, Bridges RS: Alterations in luteinizing hormone-releasing hormone release from the mediobasal hypothalamus of ovariectomized, steroid-primed middle-aged rats as measured by push-pull perfusion. Neuroendocrinology 1989;49:225-232.
76 King JC, Letourneau RJ: Luteinizing hormone-releasing hormone terminals in the median eminence of rats undergo dramatic changes after gonadectomy, as revealed by electron microscopic image analysis. Endocrinology 1994;134:1340-1351.

77 Yin W, Mendenhall JM, Monita M, Gore AC: Three-dimensional properties of $\mathrm{GnRH}$ neuroterminals in the median eminence of young and old rats. J Comp Neurol 2009;517:284295.

78 Ojeda SR, Ma YJ, Lee BJ, Prevot V: Glia-toneuron signaling and the neuroendocrine control of female puberty. Recent Prog Horm Res 2000;55:197-224.

79 Kermath BA, Riha PD, Woller MJ, Wolfe A, Gore AC: Hypothalamic molecular changes underlying natural reproductive senescence in the female rat. Endocrinology 2014;155: 3597-3609. 